\title{
No Downstaging After Short-Term Preoperative Radiotherapy in Rectal Cancer Patients
}

By C.A.M. Marijnen, I.D. Nagtegaal, E. Klein Kranenbarg, J. Hermans, C.J.H. van de Velde, J.W.H. Leer, and J.H.J.M. van Krieken for the Pathology Review Committee and the Cooperative Clinical Investigators

\begin{abstract}
Purpose: In retrospective studies, total mesorectal excision (TME) surgery has been demonstrated to result in a reduction in the number of local recurrences of rectal cancer. Reports on improved local control after preoperative, hypofractionated radiotherapy have led to the introduction of a randomized multicenter trial to evaluate the effect of TME surgery with and without preoperative radiotherapy. Treatment with preoperative radiotherapy might have an effect on the pathologic characteristics that determine staging of rectal cancer. We investigated the occurrence of downstaging in rectal cancer patients treated with and without preoperative radiotherapy.

Patients and Methods: We analyzed the differences in tumor size, number of examined lymph nodes, tumor-node-metastasis stage, and histopathologic features in 1,321 patients entered onto a randomized trial.
\end{abstract}

$I^{1}$ $\mathrm{N}$ RECTAL CANCER, the most important predictive factor for survival or recurrence after potentially curative surgery is the tumor-node-metastasis stage of the disease. This is determined by the depth of penetration through the bowel wall and the presence and number of tumor-containing lymph nodes. Both of these criteria can only be determined postoperatively.

In attempt to reduce the high local recurrence rates in rectal cancer patients after curative surgery, the value of additional preoperative ${ }^{1-10}$ or postoperative ${ }^{11-15}$ radiotherapy (RT) has been investigated in a series of clinical trials. Treatment with preoperative RT might have an effect on the pathologic characteristics that determine staging in rectal cancer patients. If such an effect occurs, the staging of rectal cancer patients who undergo only potentially curative surgery will be systematically different from the staging of

From the Departments of Clinical Oncology, Pathology, Surgery, Medical Statistics, Leiden University Medical Center, Leiden; and the Department of Pathology, University Medical Center St. Radboud, Nijmegen, the Netherlands.

Submitted August 25, 2000; accepted December 21, 2000.

Supported by a grant from the National Health Council (Ontwikkelingsgeneeskunde OWG 97/026).

Address reprint requests to C.A.M. Marijnen, MD, Department of Clinical Oncology, Leiden University Medical Center, K1-P, PO Box 9600, 2300 RC Leiden, the Netherlands; email: marijnen@lumc.nl.

(C) 2001 by American Society of Clinical Oncology.

0732-183X/01/1907-1976
The trial compared preoperative radiotherapy $(5 \times 5$ Gy) followed by TME surgery with TME surgery alone. Patients who had an interval of more than 10 days between the start of radiotherapy and surgery were excluded from analysis.

Results: Differences were observed in tumor size $(P<.001)$ and total number of examined lymph nodes $(P<.001)$. No difference in tumor or node classification was detected. The irradiated group demonstrated more poorly differentiated tumors as well as more mucinous tumors.

Conclusion: In rectal cancer patients, short-term, preoperative radiotherapy with $5 \times 5$ Gy does not lead to downstaging if the interval between the start of radiotherapy and surgery does not exceed 10 days.

J Clin Oncol 19:1976-1984. () 2001 by American Society of Clinical Oncology.

patients who receive preoperative RT followed by curative surgery. As a consequence, migration of patients from one stage to another might occur. This phenomenon, which sometimes is called Will Rogers phenomenon, is well documented in gastric cancer after D1 or D2 resection. ${ }^{16,17}$ The possible occurrence of downstaging is important to decisions for which staging is relevant, for the selection of patients for adjuvant therapy, and for comparison of different treatment strategies.

In a large Swedish rectal cancer trial, preoperative hypofractionated RT resulted in better local control than postoperative RT. ${ }^{1}$ Recent results of the SRC trial demonstrated reduced local recurrence rates and improved overall survival with a short-term $5 \times 5$ Gy preoperative RT regimen compared with surgery alone. ${ }^{10}$ This trial demonstrated an imbalance in Dukes' cancer stage groups, with more patients at Dukes' A and Dukes' B in the combined versus the surgery arm, which was considered a result of downstaging caused by the preoperative RT.

The beneficial effect of preoperative RT demonstrated in the SRC trial was observed in combination with standard surgery. ${ }^{10}$ The acknowledgment of the important role of circumferential margin involvement in the local recurrence of rectal cancer $^{18}$ has led to the introduction of total mesorectal excision (TME) surgery, as advocated by Heald $^{19}$ and Enker. ${ }^{20}$

To analyze whether preoperative RT is beneficial in TME-treated patients, a randomized, international multicenter trial was conducted under the auspices of the Dutch 
Colorectal Cancer Group to evaluate the effect of preoperative, hypofractionated RT and TME surgery versus TME surgery alone. ${ }^{21}$ The overall results are expected to be published in 2001. We have analyzed currently the occurrence of stage migration as a result of preoperative RT in patients entered onto this study.

The effect of RT on pathologic characteristics, and consequently on the occurrence of downstaging in rectal cancer, depends on total dose, fractionation size, and the interval between the start of RT and the day of surgery, which is called the overall treatment time (OTT). Trials on which patients have an OTT greater than 4 weeks generally demonstrate downstaging. Some trials have reported a decrease in the number of patients with involved lymph nodes after administration of $5 \times 5$ Gy. ${ }^{8,22}$ The present study was undertaken to assess the effect of short-term preoperative RT on tumor characteristics such as staging, grading, nodal spread, and size in resected rectal cancer specimens from a large multicenter trial with standardized RT, surgery, and pathology. ${ }^{21}$

\section{PATIENTS AND METHODS}

\section{Study Population}

Primary rectal cancer patients who were included in a large multicenter trial in the Netherlands were studied. From January 1996 through December 1999, more than 1,500 patients were randomized to receive preoperative RT followed by standardized TME surgery or TME surgery alone.

Patients entered onto the study were required to have biopsy confirmation of rectal adenocarcinoma, resectable tumor as judged by clinical examination, tumor within $15 \mathrm{~cm}$ of the anal verge, no signs of distant metastases, and no hereditary polyposis. Patients in whom a malignancy was diagnosed previously, or who had received either chemotherapy or RT to the pelvis, were not included in the study. Furthermore, patients had to be considered fit for surgery as well as for RT. Informed consent was obtained from all patients.

Randomization to RT followed by TME surgery or TME surgery alone occurred only after stratification for surgical institute and expected type of resection. Central randomization was performed with balanced lists and a block size of six. A total of 1,530 patients were included on the trial, of which 117 turned out to be ineligible for reasons listed in Table 1. To evaluate the effect of short-term preoperative RT on pathologic tumor characteristics, patients also were excluded from analysis in the RT group because either the total dose received was less than 25 Gy $(n=14)$, or the time interval between the start of radiation and surgery was greater than 10 days $(\mathrm{n}=78)$. Thus, 1,321 patients remained assessable.

\section{Preoperative $R T$}

The patients assigned to preoperative RT received a total dose of 25 Gy in five fractions for 5 to 7 days. The prescribed dose was specified according to the guidelines in the International Commission on Radiation Units Report $50 .{ }^{23}$ The clinical target volume included the primary tumor and the mesentery, with vascular supply that contained the perirectal, presacral, and internal iliac nodes (up to the S1-S2
Table 1. Patients Excluded From Analysis

\begin{tabular}{lrrr}
\hline & RT + TME & TME & Total \\
\hline Randomized & 761 & 769 & 1530 \\
Ineligible at randomization & 22 & 27 & 49 \\
No adenocarcinoma & 4 & 3 & 7 \\
Other/previous malignancy & 10 & 15 & 25 \\
Double tumor & 1 & 5 & 6 \\
Other & 7 & 4 & 11 \\
Ineligible after randomization & 45 & 23 & 68 \\
Withdrawn consent & 11 & 2 & 13 \\
Sigmoid carcinoma & 2 & - & 2 \\
Irresectable/M1 on CT scan & 9 & - & 9 \\
RT not possible & 4 & - & 4 \\
Other & 5 & 1 & 6 \\
No resection & 14 & 20 & 34 \\
Compliance RT $<$ 100\% & 92 & & 92 \\
Dose $<25$ Gy & 14 & - & 14 \\
OT $>10$ days & 78 & - & 78 \\
Total analyzed & 602 & 719 & 1321 \\
\hline
\end{tabular}

Abbreviation: $\mathrm{CT}$, computed tomography.

junction). The upper border of the planning target volume was L5-S1 in $84 \%$ of patients and S1-S2 in $16 \%$ of patients. The perineum was included if an abdominoperineal resection was planned, whereas the lower border was $3 \mathrm{~cm}$ above the anal verge if the planned operation was a low anterior resection. The irradiation was administered with a four-portal field in $26 \%$ of patients and with a three-portal field in $74 \%$ of patients.

\section{Surgery}

According to the protocol, surgery was to be performed within 10 days after the first day of irradiation. All patients underwent surgery according to the TME principles. ${ }^{19}$ The main principles of this operative technique involve sharp dissection within the true pelvis around the integral mesentery under direct vision, envelopment of the entire midrectum, and preservation of the hypogastric plexus.

\section{Pathology Procedures}

Standardized routine pathology examinations were performed in the pathology laboratories of the referring hospitals as has been described by Quirke et al. ${ }^{24}$ Pathologic information for all patients' resected tumors was recorded prospectively by pathologists from the referring hospital on a standard pathology case record form. A pathology quality manager and a pathology review committee were installed to ensure consistent quality of all pathology data and procedures. ${ }^{25}$

Careful examination of the circumferential resection margin was performed, and tumor invasion of the bowel wall and surrounding tissue was investigated. The largest diameter of the tumor was registered after fixation of the specimen. The specimens were examined for lymph nodes, and all lymph nodes found were processed for microscopic investigation.

Tumor staging was performed by use of the tumor-node-metastasis classification, ${ }^{26}$ and the Jass classification ${ }^{27}$ was used by the pathology review committee. A summary of the Jass classification is provided in the Appendix. In addition, the pathology review committee classified the tumors according to their histologic differentiation as well differentiated, moderately differentiated, poorly differentiated, and undifferentiated adenocarcinoma. The World Health Organization criteria as 
presented in 1976 by Morson and Sobin, ${ }^{28}$ with the modification of Blenkinsopp et al, ${ }^{29}$ were used. The grading decision was based on the least differentiated area. The tumor was considered mucinous if more than $50 \%$ of the adenocarcinoma was mucinous.

\section{Data Collection and Statistics}

All case record forms were sent to the central data office at the department of surgery in Leiden. After the data were checked, they were entered in a database and analyzed with the SPSS 9.0 software for Windows (SPSS, Inc, Chicago, IL).

Mann-Whitney $U$ tests were used to compare quantitative and ordered variables, and Student's $t$ test was used to analyze differences in normally distributed data between the two groups. $\chi^{2}$ tests were used to compare proportions. A $P$ value $\leq 0.05$ was considered statistically significant.

\section{Previous Randomized Trials}

To compare the effect of preoperative RT on stage migration, all randomized trials with preoperative RT were analyzed. The difference in the percentage of patients with tumor-node-metastasis stage III disease in the nonirradiated group, minus the RT plus surgery group, was calculated and plotted graphically with $95 \%$ confidence intervals.

\section{RESULTS}

\section{Patient Characteristics}

Table 2 lists distributions of age, sex, tumor localization, operation type, and distant metastases for the two treatment arms. There were no significant differences in these factors among the individual treatment arms. For the patients treated with RT, the time from initiation of RT up to and including the day of surgery (the OTT) is listed in Table 2.

\section{Pathologic Staging Characteristics}

The mean tumor size (largest diameter) was significantly smaller in the irradiated group than in the surgery-only patient group (Table 3). The mean diameter of irradiated tumors was $4.0 \mathrm{~cm}$ compared with $4.5 \mathrm{~cm}$ for the nonirradiated tumors $(P<.001)$. Nonetheless, there was no significant difference in tumor classification between the groups.

The total number of lymph nodes examined was significantly smaller in the irradiated group as compared with the nonirradiated group (Table 3; $P<.001$ ). Overall, the mean value of examined lymph nodes was 9.7 in the control group and 7.7 in the irradiated group. There was no difference between the groups in the mean number of positive lymph nodes: 1.6 in the RT group and 1.9 in the control group. In addition, in stage III tumors only, no difference between the number of involved lymph nodes was observed. The distribution between both groups with regard to node classification was balanced: $39 \%$ nodal involvement in the combined treatment arm and $42 \%$ involvement in the surgery-only arm. The distribution of tumor-node-metastasis stages was similar between both treatment arms (Fig 1). The number of
Table 2. Clinical Characteristics of Patients in the Irradiated and Nonirradiated Groups

\begin{tabular}{|c|c|c|c|c|}
\hline \multirow[b]{2}{*}{ Characteristics } & \multicolumn{2}{|c|}{$\begin{array}{l}\mathrm{RT}+\mathrm{TME} \\
(\mathrm{n}=602)\end{array}$} & \multicolumn{2}{|c|}{ TME (n = 719) } \\
\hline & No. & $\%$ & No. & $\%$ \\
\hline \multicolumn{5}{|l|}{ Age, years } \\
\hline Mean & \multicolumn{2}{|c|}{64.1} & \multicolumn{2}{|c|}{64.1} \\
\hline Range & \multicolumn{2}{|c|}{$26-88$} & \multicolumn{2}{|c|}{ 23-92 } \\
\hline \multicolumn{5}{|l|}{ Sex } \\
\hline Male & 402 & 67 & 455 & 63 \\
\hline Female & 200 & 33 & 264 & 37 \\
\hline \multicolumn{5}{|l|}{ Distance from anal verge } \\
\hline $0-5 \mathrm{~cm}$ & 174 & 29 & 224 & 32 \\
\hline $5-10 \mathrm{~cm}$ & 250 & 42 & 282 & 40 \\
\hline $10-15 \mathrm{~cm}$ & 169 & 29 & 202 & 28 \\
\hline Missing & 9 & & 11 & \\
\hline \multicolumn{5}{|l|}{ Operation type } \\
\hline $\begin{array}{l}\text { Abdominoperineal } \\
\text { resection }\end{array}$ & 183 & 31 & 220 & 30 \\
\hline Low anterior resection & 381 & 63 & 465 & 65 \\
\hline Hartmann & 38 & 6 & 34 & 5 \\
\hline \multicolumn{5}{|l|}{ Distant metastases } \\
\hline No & 568 & 94 & 679 & 94 \\
\hline Yes & 34 & 6 & 40 & 6 \\
\hline \multicolumn{5}{|l|}{ Oाт } \\
\hline 6 & 2 & 0.3 & - & \\
\hline 7 & 16 & 3 & - & \\
\hline 8 & 237 & 40 & - & \\
\hline 9 & 218 & 36 & - & \\
\hline 10 & 129 & 21 & - & \\
\hline
\end{tabular}

patients with tumor-node-metastasis stage III was 34\% in the irradiated group and $38 \%$ in the nonirradiated group.

\section{Histopathologic Characteristics}

The differentiation grades demonstrated more poorly differentiated tumors in the irradiated group than in the non irradiated group (Table 3; $P<.001$ ). There were also

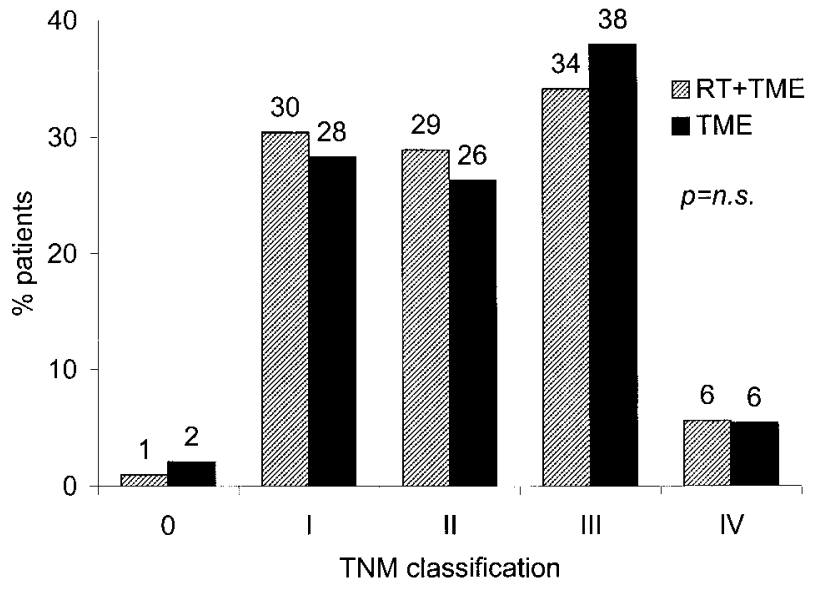

Fig 1. Distribution of tumor-node-metastasis stage by randomization arm. 
Table 3. Pathological Characteristics of Irradiated and Nonirradiated Patients

\begin{tabular}{|c|c|c|c|c|c|}
\hline & \multicolumn{2}{|c|}{$\begin{array}{l}\mathrm{RT}+\mathrm{TME} \\
(\mathrm{n}=602)\end{array}$} & \multicolumn{2}{|c|}{$\begin{array}{c}\text { TME } \\
(\mathrm{n}=719)\end{array}$} & \multirow[b]{2}{*}{$P$} \\
\hline & No. & $\%$ & No. & $\%$ & \\
\hline Tumor diameter, cm & & & & & $<.001^{*}$ \\
\hline Mean & \multicolumn{2}{|c|}{4.0} & \multicolumn{2}{|c|}{4.5} & \\
\hline SD & \multicolumn{2}{|c|}{1.7} & \multicolumn{2}{|c|}{1.8} & \\
\hline Tumor stage & & & & & $.22 \dagger$ \\
\hline 0 & 4 & 0.7 & 13 & 1.8 & \\
\hline Tis & 2 & 0.3 & 4 & 0.6 & \\
\hline 1 & 33 & 6 & 33 & 5 & \\
\hline 2 & 203 & 34 & 219 & 30 & \\
\hline 3 & 346 & 57 & 419 & 58 & \\
\hline 4 & 14 & 2 & 31 & 4 & \\
\hline Node stage & & & & & $.21 \dagger$ \\
\hline Negative & 369 & 61 & 416 & 58 & \\
\hline Positive & 233 & 39 & 303 & 42 & \\
\hline \multicolumn{6}{|l|}{ Lymph nodes } \\
\hline \multicolumn{6}{|l|}{ Total examined } \\
\hline Mean & \multicolumn{2}{|c|}{7.7} & \multicolumn{2}{|c|}{9.7} & $<.001^{*}$ \\
\hline SD & \multicolumn{2}{|c|}{6.0} & \multicolumn{2}{|c|}{6.9} & \\
\hline \multicolumn{6}{|l|}{ Positive in all patients } \\
\hline Mean & \multicolumn{2}{|c|}{1.6} & \multicolumn{2}{|c|}{1.9} & $.11^{*}$ \\
\hline SD & \multicolumn{2}{|c|}{3.6} & \multicolumn{2}{|c|}{4.1} & \\
\hline \multicolumn{6}{|l|}{$\begin{array}{l}\text { Positive in node-positive } \\
\text { patients }\end{array}$} \\
\hline Mean & \multicolumn{2}{|c|}{4.2} & \multicolumn{2}{|c|}{4.5} & $.15^{*}$ \\
\hline SD & \multicolumn{2}{|c|}{4.8} & \multicolumn{2}{|c|}{5.2} & \\
\hline Histological differentiation & & & & & $<.001^{*}$ \\
\hline No tumor & \multicolumn{2}{|l|}{4} & \multicolumn{2}{|l|}{13} & \\
\hline Well & 29 & 5 & 42 & 6 & \\
\hline Moderate & 360 & 60 & 495 & 71 & \\
\hline Poor/undifferentiated & 208 & 35 & 165 & 23 & \\
\hline Missing & \multicolumn{2}{|l|}{1} & \multicolumn{2}{|l|}{4} & \\
\hline Tumor type & & & & & $<.001 \dagger$ \\
\hline No tumor & \multicolumn{2}{|l|}{4} & 13 & & \\
\hline Adenocarcinoma & 518 & 87 & 651 & 93 & \\
\hline Mucinous carcinoma & 79 & 13 & 51 & 7 & \\
\hline Missing & 1 & & 4 & & \\
\hline
\end{tabular}

${ }^{*}$ Mann-Whitney $U$ test.

$\dagger \chi^{2}$ test.

significantly more mucinous tumors in the first group $(P<.001)$.

The proportion of peritumoral lymphocytic infiltration was scored on slides stained with hematoxylin and eosin. The irradiated tumors demonstrated extensive lymphoid reaction in $6.8 \%$ of the cases versus $17.9 \%$ in the nonirradiated tumors $(P<.001)$. The type of invasion (circumscribed $v$ diffuse) did not vary between the groups. The distribution over the Jass classification demonstrated a lower Jass classification in the irradiated group (Fig 2).

\section{Previous Randomized Trials}

To compare the effect of different preoperative RT schemes on lymph node involvement, all randomized trials

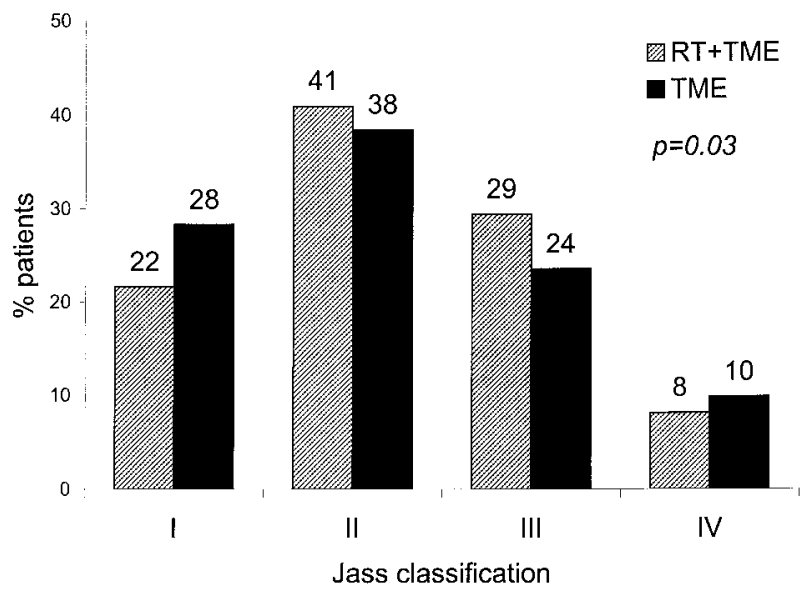

Fig 2. Distribution of Jass classification by randomization arm.

with preoperative RT for operable rectal cancer were analyzed. Table 4 summarizes these trials with dose, fractionation, and overall treatment time and the differences in tumor stage, size, number of lymph nodes examined, and histologic differentiation if published. The percentage of stage III tumors is expressed in comparison with stage I and II tumors unless otherwise stated. In general, the trials with a long OTT demonstrate more downstaging than trials with a short OTT. The SRC trial ${ }^{22}$ is divided in two subgroups: patients with an OTT less than 10 days and patients with an OTT greater than 10 days. Tumor size was smaller in all irradiated groups than in the surgery-only groups.

To visualize the differences in the percentage of patients with tumor-node-metastasis stage III, the $95 \%$ confidence bars of the difference are plotted in Fig 3. The trials are grouped by the duration of the OTT.

\section{DISCUSSION}

These results demonstrate that after short-term preoperative RT, a decrease in the tumor size and the number of recovered lymph nodes is observed, but there is no change in the tumor classification and node classification. Therefore, downstaging has not occurred in our trial. We suggest that the disappearance of negative lymph nodes is caused by rapid apoptosis of lymphocytes in contrast to tumor cells.

Preoperative RT is administered for several indications. Apart from reduction in the number of local recurrences, downstaging is one of the main purposes of conventional schemes, which now are combined frequently with chemotherapy. Tumor reduction is useful to achieve resectability in locally advanced tumors or to allow sphinctersaving procedures in low tumors. It is unlikely that a greater number of sphincter-saving procedures can be performed after short-term RT, because downstaging is 
not the mechanism by which the reduction in local recurrence is achieved.

According to the literature, several factors seem to play a role in the occurrence of downstaging after preoperative RT. One factor is the fraction size and total dose applied. This is directly correlated with the time interval between the first fraction of RT and the date of surgery (the so-called OTT). In studies in which doses of $40 \mathrm{~Gy}$ or more are given in a conventional fractionation scheme, this automatically leads to an OTT of more than 4 weeks, which provides time for the tumor to shrink. In short-term RT, however, the overall treatment time is usually 2 weeks at most. The relevance of the interval between RT and surgery in rectal cancer has been investigated recently by Francois et al. ${ }^{30}$ After a dose of 30 to $39 \mathrm{~Gy}$, they found no difference in stage III tumors following an interval of 2 or 6 weeks between RT and surgery. This might be explained by the median interval between RT and surgery, which was already 13 days in the short interval (range, 1 to 63 days).

There have been several reports on downstaging in rectal cancer after randomized trials with preoperative RT. A summary of those studies is listed in Table 4 and Fig 3. Most studies with an interval that exceeds 4 weeks demonstrate fewer patients with Dukes' C stage in the irradiated group. In the European Organization for Research and Treatment of Cancer trial, ${ }^{2}$ surgery was performed immediately after RT. No difference in Dukes' C staging was observed. The reports on downstaging in the short-term RT group $(<2$ weeks) varied. No difference was seen (nor expected) in the Medical Research
Council I trial ${ }^{7}$ in the group that received $1 \times 5$ Gy or in the Toronto trial. This can be attributed to the low total dose.

Of the other trials with a short OTT, most did not detect downstaging. The SRC trial demonstrates less nodal involvement if all patients are analyzed together. If the groups are corrected for overall treatment time, the downstaging disappears completely. The Stockholm II trial also demonstrates downstaging, but of the 557 patients analyzed, 316 were also included in the report by Graf et al. ${ }^{10,22}$

In our study, the OTT was not more than 10 days. This interval is too short for the tumor cells to disappear, and it explains our finding that there was no downstaging. We found smaller tumors in the RT arm, which is in accordance with the trials mentioned previously. When tumor size was reported, tumors were smaller in the RT group. To explain the differences in tumor diameter, we investigated whether the amount of lymphoid infiltration was a contributor. This hypothesis was developed because the number of lymph nodes found in the specimens decreased significantly in the irradiated group, and we found less lymphoid infiltration in irradiated tumors. There was no correlation between tumor size and extension of infiltration.

The number of lymph nodes examined was significantly lower in the irradiated group, but no decrease in the number of positive lymph nodes was observed. This is explained by the fact that lymphocytes can undergo cell death within hours after RT without cell division, whereas tumor cells need more time to undergo cell death. ${ }^{31}$ In patients with long intervals between

Table 4. Randomized Trials on Downstaging After Preoperative Radiotherapy for Rectal Cancer

\begin{tabular}{|c|c|c|c|c|c|c|c|c|c|c|c|}
\hline \multirow[b]{2}{*}{ Trial } & \multirow[b]{2}{*}{ No. of Patients } & \multirow[b]{2}{*}{$\begin{array}{c}\text { Fraction } \times \\
\text { Dose, Gy }\end{array}$} & \multirow[b]{2}{*}{$\begin{array}{c}\text { OTT } \\
\text { (weeks) }\end{array}$} & \multicolumn{2}{|c|}{ TNM III } & \multicolumn{2}{|c|}{ Tumor Size* } & \multicolumn{2}{|c|}{ Lymph Nodes $\dagger$} & \multicolumn{2}{|c|}{ Histology $\neq$} \\
\hline & & & & $\begin{array}{c}\mathrm{RT}+\mathrm{S} \\
(\%)\end{array}$ & $\begin{array}{c}S \\
(\%)\end{array}$ & $\begin{array}{c}\mathrm{RT}+\mathrm{S} \\
(\%)\end{array}$ & $S(\%)$ & $\mathrm{RT}+\mathrm{S}$ & $\mathrm{s}$ & $\begin{array}{c}\mathrm{RT}+\mathrm{S} \\
(\%)\end{array}$ & $\begin{array}{c}S \\
(\%)\end{array}$ \\
\hline Bergen $^{4}$ & 269 & $18 \times 1.75$ & 7 & 18 & 28 & $3.0 \mathrm{~cm}$ & $4.0 \mathrm{~cm}$ & 2 & 4 & 9 & 8 \\
\hline EORTC $\|^{2}$ & 341 & $15 \times 2.3$ & 4 & 34 & 34 & & & & & & \\
\hline VASOG $\|^{33}$ & 320 & $18 \times 1.75$ & 6 & 36 & 42 & & & & & & \\
\hline$M R C \|^{7}$ & 248 & $20 \times 2$ & $>8$ & 30 & 59 & 68 & 36 & 22 & 52 & 16 & 15 \\
\hline Toronto $^{34}$ & 125 & $1 \times 5$ & 1 day & 44 & 29 & & & & & & \\
\hline$M R C 1^{6}$ & 824 & $1 \times 5$ & 1 & 46 & 45 & 42 & 36 & 4.7 & 4.9 & 20 & 16 \\
\hline VASOG $1^{35}$ & 613 & $10 \times 2$ & $>2$ & 24 & 38 & & & & & & \\
\hline MRC $1^{6}$ & 824 & $10 \times 2$ & 3 & 36 & 45 & 54 & 36 & 3.2 & 4.9 & 15 & 16 \\
\hline RCG/ICRG ${ }^{3}$ & 468 & $3 \times 5$ & 1 & 43 & 44 & & & & & & \\
\hline NWRCG $^{36}$ & 284 & $4 \times 5$ & $1-2$ & $47 \S$ & $39 \S$ & 50 & 42 & & & 19 & 4 \\
\hline Stockholm $1^{9}$ & 849 & $5 \times 5$ & $1-2$ & 32 & 31 & & & & & 25 & 15 \\
\hline Stockholm $\|^{37}$ & 557 & $5 \times 5$ & $1-2$ & 28 & 38 & & & & & & \\
\hline $\mathrm{SRC}^{22}$ & 1316 & $5 \times 5$ & $1-2$ & 33 & 42 & $4.2 \mathrm{~cm}$ & $4.8 \mathrm{~cm}$ & & & & \\
\hline Current trial & 1530 & $5 \times 5$ & $1-2$ & 34 & 38 & $4.0 \mathrm{~cm}$ & $4.5 \mathrm{~cm}$ & 7.7 & 9.7 & 35 & 23 \\
\hline
\end{tabular}

Abbreviations: TNM, tumo-node-metastasis stage; S, surgery; EORTC, European Organization for Research and Treatment of Cancer; VASOG, Veterans' Administration Surgical Oncology Group; MRC, Medical Research Council; RCG/ICRG, Rectal Cancer Group/Imperial Cancer Research Fund; NWRCG, Northwest Region Rectal Cancer Group; SRC, Swedish Rectal Cancer.

${ }^{*}$ Size in $\mathrm{cm}$ (Bergen median, others mean) or percentage of patients with tumors $<5 \mathrm{~cm}$.

†Number of lymph nodes or percentage of patients with $>7$ lymph nodes (MRC II).

†Percentage of poorly differentiated tumors.

§TNM stage III and IV. 


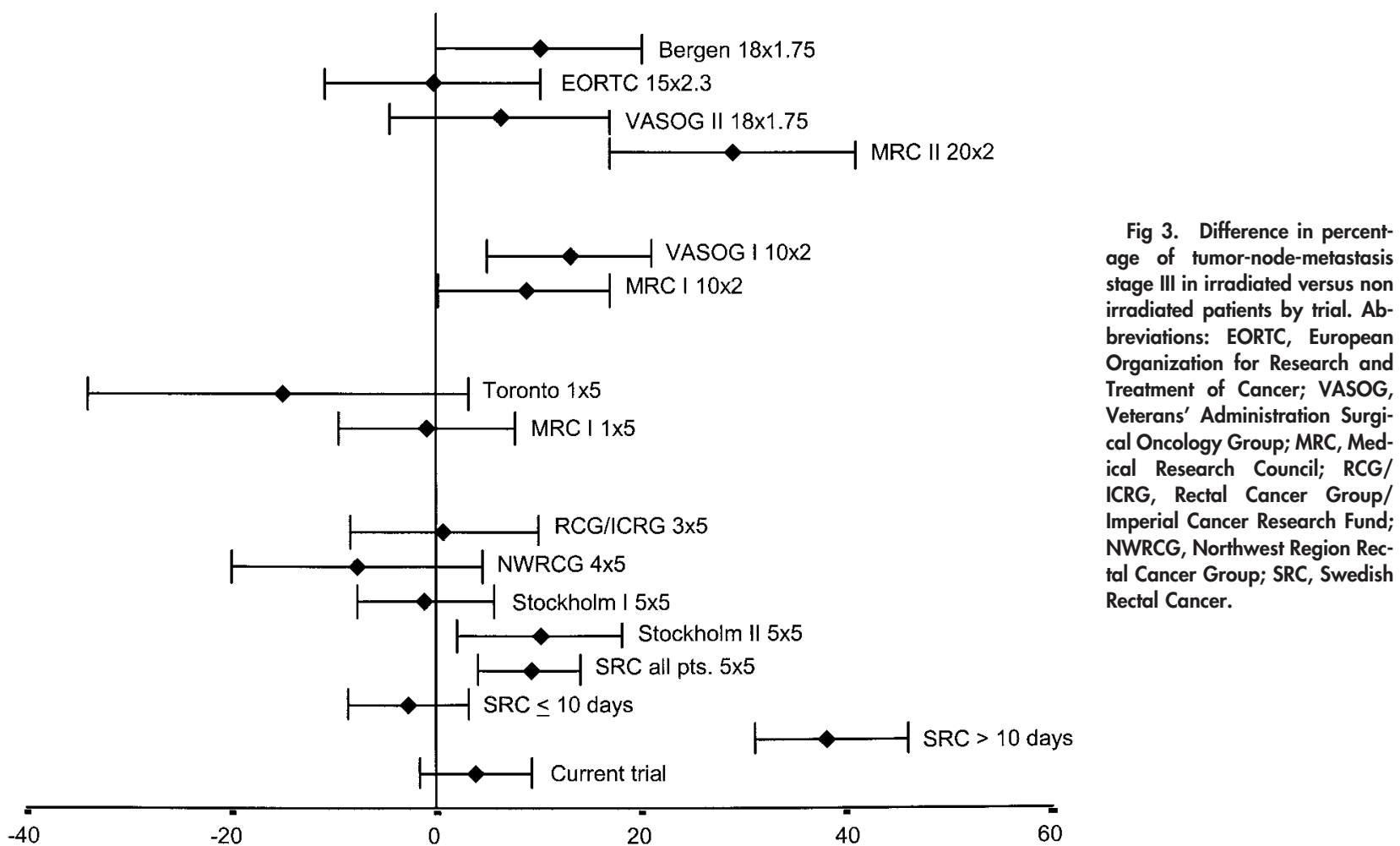

RT and surgery, lymphocytes reappear and tumor cells die, and these events lead to downstaging.

The differences in histology have been observed previously. The Northwest Region Rectal Cancer Group trial and the Stockholm I trial both reported an increase in poorly differentiated tumors in the irradiated groups. This was not observed in the Bergen and Medical Research Council II trial, both of which had OTTs of more than 4 weeks; the disappearance of cells is a possible explanation. Because grading is scored on the basis of the worst area, the presence of less lymphocytes increases the chance of finding such an area.

Despite the differences found after irradiation, no difference was found in tumor-node-metastasis stage. However, the irradiated group demonstrated a higher Jass classification, which resulted from the disappearance of the lymphocytic infiltrate, one of the Jass classification parameters. Therefore, the Jass classification is of limited value in comparing patients who have been irradiated preoperatively with nonirradiated patients.

In January 2000, the Dutch Colorectal Cancer Group initiated a new multicenter trial with optional randomization for preoperative RT until the results of the TME trial are known. Patients with tumor-node-metastasis stage II or III are randomized postoperatively for adjuvant chemotherapy (fluorouracil and leucovorin). ${ }^{32}$ The absence of downstaging guarantees a balanced distribution of tumor-node-metastasis stages across the different randomization groups, which prevents stage migration that would influence the eventual outcome of this new trial.

In addition, we conclude that short-term, preoperative RT does not contribute to downstaging if the overall treatment time is less than 10 days. Results that indicate better survival or fewer recurrences after this type of RT must be attributed to the effect of the RT.

Table 5. Jass Classification: Scoring Criteria

\begin{tabular}{lc}
\hline \multicolumn{1}{c}{ Criterion } & Score \\
\hline Invasion through the bowel wall & \\
Limited to bowel wall & 0 \\
Transmural & 1 \\
Margin of the tumor & \\
Pushing & 0 \\
Infiltrating & 1 \\
Peritumoral lymphocytic infiltrate & \\
Conspicious & 0 \\
Scant/absent & 1 \\
Lymph node metastases & \\
Negative & 0 \\
1-4 positive & 1 \\
$>4$ positive & 2 \\
\hline Jass Groups & Total Score \\
\hline I & $0-1$ \\
II & 2 \\
III & 3 \\
IV & $4-5$ \\
\hline
\end{tabular}


The pathology review committee is as follows: E. Bloemena, Vrije Universiteit, Amsterdam; G. J. Offerhaus, Academisch Medisch Centrum, Amsterdam; M.F.L. van Velthuysen, Antoni van Leeuwenhoekhuis, Amsterdam; J. Los, St. Ignatius Ziekenhuis, Breda; P.J. Westenend, PA laboratorium, Dordrecht; H.M. Peters, I.W.N. Tan-Go, Stichting PAMM, Eindhoven; A.J.K. Grond, Lab. Volksgezondheid Friesland, Leeuwarden; J.W. Arends, Academisch Ziekenhuis, Maastricht; A. Maes, J.C. Verhaar, Stichting Pathan, Rotterdam; and A.A.M. van der Wurff, Laboratorium Centraal Brabant, Tilburg.

Cooperative clinical investigators include the following:

Surgeons: A.B. Bijnen, P. de Ruiter, Medisch Centrum Alkmaar, Alkmaar; B. van Ooijen, Algemeen Christelijk Ziekenhuis Eemland Locatie de Lichtenberg, Mersfoort; D. van Geldere, R.P.A. Boom, Ziekenhuis Amstelveen, Amstelveen; R.P. Bleichrodt, S. Meyer, Academisch Ziekenhuis Vrije Universiteit, Amsterdam; R.M.J.M. Butzelaar, E.Ph. Steller, Sint Lucas Andreas Ziekenhuis, Locatie Lucas, Amsterdam; W.F. van Tets, A.C.H. Boissevain, Sint Lucas Andreas Ziekenhuis, Locatie Andreas, Amsterdam; F.J. Sjardin, BovenIJ Ziekenhuis, Amsterdam; J.F.M. Slors, Academisch Medisch Centrum, Amsterdam; W.H. Bouma, J.G.J. Roussel, Gelre Ziekenhuizen, Locatie Lukas Ziekenhuiscentrum Apeldoorn, Apeldoorn; J.H.G. Klinkenbijl, E.J. Spillenaar Bilgen, Ziekenhuis Rijnstate, Arnhem; Ph.M. Kruyt, W.K. de Roos, Stichting Ziekenhuisvoorzieningen Gelderse Vallei Locatie Ziekenhuis Gelderse Vallei Bennekom, Bennekom; E.J.R. Slingenberg, P.D. de Rooij, Sint Ziekenhuis Lievensberg, Bergen op Zoom; M.A.J.M. Hunfeld, Rode Kruis Ziekenhuis, Beverwijk; A.L.A. Meersman, Maasziekenhuis Boxmeer, Boxmeer; J.K.S. Nuytinck, Ignatius Ziekenhuis Breda, Breda; R.M.P.H. Crolla, Ziekenhuis de Baronie, Breda; J. van der Bijl, Atrium Brunssum, Atrium Heerlen, Brunssum, Heerlen; G.W.M. Tetteroo, IJsselland Ziekenhuis, CAPELLE A/D IJSSEL; L.P.S. Stassen, P.W. de Graaf, Reinier de Graaf Groep Loc. Reinier de Graaf Gasthuis, Delft; W.A.H. Gelderman, F.G.J. Willekens, Bosch Medicentrum Locatie Groot Ziekengasthuis, Den Bosch; I.P.T. van Bebber, E.J. Carol, Stichting Carolus-Liduina-Lindelust Ziekenhuis Locatie Carolus Ziekenhuis, Den Bosch; G.W. Kastelein, H. Boutkan, Stichting Juliana Kinderziekenhuis/Rode Kruis Ziekenhuis Locatie Rode Kruis Ziekenhuis, Den Haag; Ch. Ulrich, B.C. de Vries, Medisch Centrum Haaglanden Locatie Westeinde, Den Haag; H.J. Smeets, J.M. Heslinga, Stichting Bronovo-Nebo, Ziekenhuis Bronovo, Den Haag; W. H. Steup, P.V.M. Pahlplatz, Ziekenhuis Leyenburg, Den Haag; P. Heres, J.A. van Oijen, Stichting het van Weel-Bethesda Ziekenhuis, Dirksland; M. van Hillo, Stichting Talma Sionsberg, Dokkum; R.J. Oostenbroek, K.G. Tan, Albert Schweitzer Ziekenhuis Locatie Dordwijk, Dordrecht; H.C.J. van der Mijle, Christelijk Ziekenhuis Nij Smellinghe, Drachten; R. Looijen, Christelijk Ziekenhuis Nij Smellinghe, Drachten; H.J.T. Rutten, J.J. Jakimowicz, Catharina Ziekenhuis, Eindhoven; O.J. Repelaer van Driel, P. H. M. Reemst, Diaconessenhuis Eindhoven, Eindhoven; E.J.Th. Luiten, R.F.T.A. Assmann, Sint Annaziekenhuis, GELDROP; C.M. Dijkhuis, Oosterscheldeziekenhuis, Goes; R.T. Ottow, Het Groene Hart Ziekenhuis Locatie Bleuland, Gouda; J.T.M. Plukker, Academisch Ziekenhuis Groningen, Groningen; E.J. Boerma, R. Silvis, Kennemer Gasthuis Locatie Deo, Haarlem; J.H. Tomee, Stichting Streekziekenhuis Coevorden-Hardenberg Locatie Röpcke Zweers, Hardenberg; G.J.M. Akkersdijk, Spaarne Ziekenhuis, Heemstede; C.G.B.M. Rupert, de Tjongerschans, Ziekenhuis Heerenveen, Heerenveen; G.J.C.M. Niessen, G. Verspui, Elkerliek Ziekenhuis Locatie Helmond, Helmond; J.H. Kroesen, J.W. Juttmann, Ziekenhuis Hilversum, Hilversum; J.W.D. de Waard, M.W.C. de Jonge, Westfries Gasthuis Locatie Sint Jan, Hoorn; D.B.W. de Roy van Zuidewijn, W. Dahmen, Medisch Centrum Leeuwarden Locatie Zuid, Leeuwarden; R. Vree, J.A. Zonnevylle, Diaconessenhuis Leiden, Leiden; C.J.H. van de Velde, R.A.E.M. Tollenaar, Lumc, Leiden; P.A. Neijenhuis, S.A. da Costa, S.K. Adhin, Rijnland Ziekenhuis Locatie Sint Elisabeth, Leiderdorp; F.J. Idenburg, Medisch Centrum Haaglanden Locatie Antoniushove, Leidschendam; H. van der Veen, IJsselmeerziekenhuizen Loc. Zuiderzeeziekenhuis, Lelystad; C.E.A.M. Hoynck van Papendrecht, IJsselmeerziekenhuizen Locatie Zuiderzeeziekenhuis, Lelystad; C.G.M.I. Baeten, M.F. von Meyenfeldt, G.L. Beets, Academisch Ziekenhuis Maastricht, Maastricht; T. Wobbes, Academisch Ziekenhuis Nijmegen Sint Radboud, Nijmegen; E.D.M. Bruggink, L.J.A. Strobbe, Canisius-Wilhelmina Ziekenhuis Nijmegen, Nijmegen; O.J. van West, R.A.J. Dörr, Pasteurziekenhuis, Oosterhout; C.D. van Duyn, Ziekenhuis Bernhoven Locatie Oss, OSS; J.W.M. Bol, Th.A.A. van den Broek, Waterlandziekenhuis, Purmerend; J.M.H. Debets, R. J. A. Estourgie, Laurentius Ziekenhuis, Roermond; H.W.P.M. Kemperman, Ziekenhuis Franciscus, Roosendaal; H.F. Veen, W.F. Weidema, C.J. van Steensel, Ikazia Ziekenhuis, Rotterdam; F. Logeman, A.A.E.A. de Smet, Sint Clara Ziekenhuis, Rotterdam; T. Wiggers, A.W.K. S. Marinelli, Academisch Ziekenhuis Rotterdam, Daniel den Hoed Kliniek, Rotterdam; J.H. Driebeek-van Dam, Havenziekenhuis, Rotterdam; W.R. Schouten, P.P.L.O. Coene, Academisch Ziekenhuis Rotterdam, Dijkzigt, Rotterdam; M.A. Paul, Zuiderziekenhuis, Rotterdam; J.J. van Bruggen, Schieland Ziekenhuis, Schiedam; E.J. Mulder, Antonius Ziekenhuis, Sneek; R. den Toom, A.J. van Beek, Ruwaard van Putten Ziekenhuis, Spijkenisse; S.J. Brenninkmeyer, G.P. Gerritsen, TweeSteden ziekenhuis, Tilburg; H.J.M. Oostvogel, J.A. Roukema, Sint Elisabeth Ziekenhuis, Tilburg; E.B.M. Theunissen, Mesos, Medisch Centrum Locatie Overvecht, Utrecht; L.W.M. Janssen, A. Hennipman, Universitair Medisch Centrum Utrecht, Utrecht; A.J.M. van Wieringen, Mesos, Medisch Centrum Locatie Oudenrijn, Utrecht; A. Pronk, P. Leguit, Diakonessenhuis, Utrecht; F. A.A.M. Croiset van Uchelen, R.M.H. Roumen, Sint Joseph Ziekenhuis, Veldhoven; C.L.H. van Berlo, J.F.M. Reinders, Sint Maartens Gasthuis, Venlo; C.D.G.W. Verheij, Sint Elisabeth Ziekenhuis, Venray; J.H. ten Thije, Ziekenhuis Walcheren, Vlissingen; W. van Overhagen, I.H. Oei, Reinier de Graaf Groep Locatie Diaconessenhuis Voorburg, Voorburg; E.M.G. Leerkotte, J. W.A. van Luijt, TweeSteden ziekenhuis, Waalwijk; H.C.M. Verkooyen, J.A.L. Jansen, Sint Jans-Gasthuis, Weert; J. Merkx, J.P. Vente, Hofpoort Ziekenhuis, Woerden; H. de Morree, Stichting Oosterscheldeziekenhuizen, Zierikzee; P.J.J. van Rijn, 't Lange Land Ziekenhuis, Zoetermeer; and W.F. Blom, Albert Schweitzer Ziekenhuis Locatie Zwijndrecht, Zwijndrecht.

Pathologists: J.P.A. Baak, Medisch Centrum Alkmaar, Alkmaar; H. Barrowclough, Algemeen Christelijk Ziekenhuis Eemland Locatie de Lichtenberg, AMersfoort; G.J.A. Offerhaus, Academisch Medisch Centrum, Amsterdam; G. Brutel de la Riviere, Sint Lucas Andreas Ziekenhuis Locatie Sint Lucas, Amsterdam; M.L.F. van Velthuysen, Antoni van Leeuwenhoekziekenhuis, Amsterdam; B.A. van de Wiel, Sint Lucas Andreas Ziekenhuis Locatie Andreas, Amsterdam; H.H. Oushoorn, BovenIJ Ziekenhuis, Amsterdam; Th.A.J.M. Manschot, Gelre Ziekenhuizen Locatie Lukas Ziekenhuiscentrum Apeldoorn, Apeldoorn; J.M. Wiersma-van Tilburg, Ziekenhuis Rijnstate, Arnhem; V. Potters, Stichting Ziekenhuis Lievensberg, Bergen op Zoom; H.V. Stel, Ziekenhuis Gooi-Noord, Blaricum; J. Los, Ignatius Ziekenhuis Breda, Breda; G.W. Verdonk, Atrium Brunssum, Brunssum; C. van Krimpen, S.H. Sastrowijoto, E.M. van der Loo, Stichting Diagnostisch Centrum Stichting Samenwerkende Delftse Ziekenhuizen, Delft; H.A. Meijer, Bosch Medicentrum Locatie Groot Ziekengasthuis, Den Bosch; P. Blok, Ziekenhuis Leyenburg, Den Haag; C.J. Tinga, Stichting Bronovo-Nebo, Ziekenhuis Bronovo, Den Haag; E.C.M. Ooms, Medisch Centrum Haaglanden Locatie Westeinde, Den Haag; 


\section{APPENDIX (Cont'd)}

C. M. Bruijn-van Duinen, Ziekenhuis Leyenburg, Den Haag; J.W. Steffelaar, Stichting Juliana Kinderziekenhuis/Rode Kruis Ziekenhuis Locatie Rode Kruis Ziekenhuis, Den Haag; P.J. Westenend, Pathologisch Laboratorium voor Dordrecht en omstreken, Dordrecht; I. W. N. Tan-Go, H.M. Peters, Stichting Pathologische Anatomie en Medische Microbiologie, Eindhoven; E.J.M. Ahsmann, Stichting LaboratoriaGoudse Ziekenhuizen, Gouda; J. F. Keuning, Stichting Pathologisch Anatomisch Laboratorium Kennemerland, Haarlem; K. van Groningen, Spaarne Ziekenhuis, Heemstede; P.H.M.H. Theunissen, Atrium Heerlen, Heerlen; F.J. J. M. van Merrienboer, Elkerliek Ziekenhuis Locatie Helmond, Helmond; G. Freling, Ziekenhuis Bethesda, Hoogeveen; A.J.K. Grond, Laboratorium voor de Volksgezondheid in Friesland, Leeuwarden; M.C.B. Gorsira, Diaconessenhuis Leiden, Leiden; J.J. Calame, Rijnland Ziekenhuis Locatie Sint Elisabeth, Leiderdorp; E.A. Neefjes-Borst, IJsselmeerziekenhuizen Locatie Zuiderzeeziekenhuis, Lelystad; J.W. Arends, academisch ziekenhuis Maastricht, Maastricht; A. P. Runsink, Streeklaboratorium "Zeeland," Middelburg; C.A. Seldenrijk, Stichting Sint Antonius Ziekenhuis, Nieuwegein; J.H.J.M. van Krieken, Academisch Ziekenhuis Nijmegen St. Radboud, Nijmegen; M. Mravunac, Canisius-Wilhelmina Ziekenhuis Nijmegen, Nijmegen; W.S. Kwee, Laurentius Ziekenhuis, Roermond; H. van Dekken, Academisch Ziekenhuis Rotterdam, Daniel den Hoed Kliniek, Rotterdam; J.C. Verhaar, Stichting Pathan, Rotterdam; N.A. L. van Kaam, Stichting Pathan, Rotterdam; H. van Dekken, Academisch Ziekenhuis Rotterdam, Dijkzigt, Rotterdam; R.W.M. Giard, Sint Clara Ziekenhuis, Rotterdam; H. Beerman, Zuiderziekenhuis, Rotterdam; A.A.M. van der Wurff, Sint Elisabeth Ziekenhuis, Tilburg; M.E.I. Schipper, Universitair Medisch Centrum Utrecht Locatie Academisch Ziekenhuis Utrecht, Utrecht; H.M. Ruitenberg, Diakonessenhuis, Utrecht; R.F.M. Schapers, Stichting Pathologisch Laboratorium, Venlo; A.P. Willig, Sint Jans-Gasthuis, Weert; and A.G. Balk, Stichting Ziekenhuis De Heel, Zaandam.

Radiotherapists: E.H.J.M. Rutten, Medisch Centrum Alkmaar, Alkmaar; D. Gonzalez Gonzalez, G. van Tienhoven, Academisch Medisch Centrum, Amsterdam; B.J. Slotman, J.A. Langendijk, Academisch Ziekenhuis Vrije Universiteit, Amsterdam; G.M.M. Bartelink, B.M.P. Aleman, Antoni van Leeuwenhoekziekenhuis, Amsterdam; A. H. Westenberg, Arnhems Radiotherapeutisch Instituur, Arnhem; J. Pomp, Reinier de Graaf Gasthuis, Delft; C.C.E. Koning, R.G.J. Wiggenraad, Medisch Centrum Haaglanden Locatie Westeinde, Den Haag; F.M. Gescher, Ziekenhuis Leyenburg, Den Haag; J.J.F.M. Immerzeel, A.C.A. Mak, Radiotherapeutisch Instituut Stedendriehoek en Omstreken, Deventer; J.G. Ribot, H. Martijn, Catharina Ziekenhuis, Eindhoven; D.F.M. de Haas-Kock, Stichting Radiotherapeutisch Instituut Limburg, Heerlen; G. Botke, A. Slot, Radiotherapeutisch Instituut Friesland, Leeuwarden; E.M. Noordijk, Leids Universitair Medisch Centrum, Leiden; Ph. Lambin, Academisch Ziekenhuis Maastricht, Maastricht; J.W.H. Leer, J. Hoogenhout, Academisch Ziekenhuis Nijmegen Sint Radboud, Nijmegen; Academisch Ziekenhuis Nijmegen Sint Radboud, Nijmegen; P.C. Levendag, P.E.J. Hanssens, Academisch Ziekenhuis Rotterdam, Daniel den Hoed Kliniek, Rotterdam; G.S.J. Bunnik, K.A.J. de Winter, dokter Bernard Verbeeten Instituut, Tilburg; J.J. Batterman, H.K. Wijrdeman, Universitair Medisch Centrum Utrecht, Utrecht; and J.M. Tabak, M.F.H. Dielwart, Zeeuws Radiotherapeutisch Instituut, Vlissingen.

Note: A summary of the Jass classification system is listed in Table 5.

\section{REFERENCES}

1. Frykholm GJ, Glimelius B, Pahlman L: Preoperative or postoperative irradiation in adenocarcinoma of the rectum: Final treatment results of a randomized trial and an evaluation of late secondary effects. Dis Colon Rectum 36:564-572, 1993

2. Gerard A, Buyse M, Nordlinger B, et al: Preoperative radiotherapy as adjuvant treatment in rectal cancer: Final results of a randomized study of the European Organization for Research and Treatment of Cancer (EORTC). Ann Surg 208:606-614, 1988

3. Goldberg PA, Nicholls RJ, Porter NH, et al: Long-term results of a randomised trial of short-course low-dose adjuvant pre-operative radiotherapy for rectal cancer: Reduction in local treatment failure. Eur J Cancer 30A:1602-1606, 1994

4. Horn A, Morild I, Dahl O: Tumour shrinkage and down staging after preoperative radiation of rectal adenocarcinomas. Radiother Oncol 18:19-28, 1990

5. Marsh PJ, James RD, Schofield PF: Adjuvant preoperative radiotherapy for locally advanced rectal carcinoma: Results of a prospective, randomized trial. Dis Colon Rectum 37:1205-1214, 1994

6. Medical Research Council Rectal Cancer Working Party: A trial of preoperative radiotherapy in the management of operable rectal cancer. Br J Surg 69:513-519, 1982

7. Medical Research Council Rectal Cancer Working Party: Randomised trial of surgery alone versus radiotherapy followed by surgery for potentially operable locally advanced rectal cancer. Lancet 348 : 1605-1610, 1996
8. Stockholm Colorectal Cancer Study Group: Randomized study on preoperative radiotherapy in rectal carcinoma. Ann Surg Oncol 3:423-430, 1996

9. Stockholm Rectal Cancer Study Group: Preoperative short-term radiation therapy in operable rectal carcinoma: A prospective randomized trial. Cancer 66:49-55, 1990

10. Swedish Rectal Cancer Trial: Improved survival with preoperative radiotherapy in resectable rectal cancer. N Engl J Med 336:980987, 1997

11. Balslev I, Pedersen M, Teglbjaerg PS, et al: Postoperative radiotherapy in Dukes' B and C carcinoma of the rectum and rectosigmoid: A randomized multicenter study. Cancer 58:22-28, 1986

12. Fisher B, Wolmark N, Rockette H, et al: Postoperative adjuvant chemotherapy or radiation therapy for rectal cancer: Results from NSABP protocol R-01. J Natl Cancer Inst 80:21-29, 1988

13. Gastrointestinal Tumor Study Group: Prolongation of the disease-free interval in surgically treated rectal carcinoma. N Engl J Med 312:1465-1472, 1985

14. Medical Research Council Rectal Cancer Working Party: Randomised trial of surgery alone versus surgery followed by radiotherapy for mobile cancer of the rectum. Lancet 348:1610-1614, 1996

15. Treurniet-Donker AD, van Putten WL, Wereldsma JC, et al: Postoperative radiation therapy for rectal cancer: An interim analysis of a prospective, randomized multicenter trial in the Netherlands. Cancer 67:2042-2048, 1991 
16. Feinstein AR, Sosin DM, Wells CK: The Will Rogers phenomenon: Stage migration and new diagnostic techniques as a source of misleading statistics for survival in cancer. N Engl J Med 312:16041608,1985

17. Bunt AM, Hermans J, Smit VT, et al: Surgical/pathologic-stage migration confounds comparisons of gastric cancer survival rates between Japan and Western countries. J Clin Oncol 13:19-25, 1995

18. Adam IJ, Mohamdee MO, Martin IG, et al: Role of circumferential margin involvement in the local recurrence of rectal cancer. Lancet 344:707-711, 1994

19. Heald RJ: Rectal cancer: The surgical options. Eur J Cancer 31A:1189-1192, 1995

20. Enker WE: Potency, cure, and local control in the operative treatment of rectal cancer. Arch Surg 127:1396-1401, 1992

21. Kapiteijn E, Kranenbarg EK, Steup WH, et al: Total mesorectal excision (TME) with or without preoperative radiotherapy in the treatment of primary rectal cancer: Prospective randomised trial with standard operative and histopathological techniques-Dutch ColoRectal Cancer Group. Eur J Surg 165:410-420, 1999

22. Graf W, Dahlberg M, Osman MM, et al: Short-term preoperative radiotherapy results in down-staging of rectal cancer: A study of 1316 patients. Radiother Oncol 43:133-137, 1997

23. International Commission on Radiation Units and Measurements: Prescribing, Recording, and Reporting Photon Beam Therapy. ICRU Report 50. Bethesda, MD, International Commission on Radiation Units and Measurements, 1993

24. Quirke P, Durdey P, Dixon MF, et al: Local recurrence of rectal adenocarcinoma due to inadequate surgical resection: Histopathological study of lateral tumour spread and surgical excision. Lancet 2:996-999, 1986

25. Nagtegaal ID, Kranenbarg EK, Hermans J, et al: Pathology data in the central databases of multicenter randomized trials need to be based on pathology reports and controlled by trained quality managers. J Clin Oncol 18:1771-1779, 2000

26. Sobin LH, Wittekind Ch: UICC TNM Classification of Malignant Tumours (ed 5). New York, NY, Wiley, 1997, pp 66-69
27. Jass JR, Love SB, Northover JM: A new prognostic classification of rectal cancer. Lancet 1:1303-1306, 1987

28. Morson BC, Sobin LH: Histological typing of intestinal tumours: International histological classification of tumours. Geneva, Switzerland, World Health Organization, 1976

29. Blenkinsopp WK, Stewart-Brown S, Blesovsky L, et al: Histopathology reporting in large bowel cancer. J Clin Pathol 34:509-513, 1981

30. Francois Y, Nemoz CJ, Baulieux J, et al: Influence of the interval between preoperative radiation therapy and surgery on downstaging and on the rate of sphincter-sparing surgery for rectal cancer: The Lyon R90-01 randomized trial. J Clin Oncol 17:23961999

31. Lowenthal JW, Harris AW: Activation of mouse lymphocytes inhibits induction of rapid cell death by $\mathrm{x}$-irradiation. J Immunol 135:1119-1125, 1985

32. Dutch Colorectal Cancer Group: Preoperative radiotherapy and/or adjuvant chemotherapy combined with TME-surgery in operable rectal cancer. CKVO 1999-03

33. Higgins GA, Huphrey EW, Dwight RW, et al: Preoperative radiation and surgery for cancer of the rectum: Veterans Administration Surgical Oncology Group Trial II. Cancer 58:352-359, 1986

34. Rider WD, Palmer JA, Mahoney LJ, et al: Preoperative irradiation in operable cancer of the rectum: Report of the Toronto trial. Can J Surg 20:335-338, 1977

35. Roswit B, Higgins GA, Keehn RJ: Preoperative irradiation for carcinoma of the rectum and rectosigmoid colon: Report of a National Veterans Administration randomized study. Cancer 35:1597-1602, 1975

36. James RD, Haboubi N, Schofield PF, et al: Prognostic factors in colorectal carcinoma treated by preoperative radiotherapy and immediate surgery. Dis Colon rectum 34:546-551, 1991

37. Holm T, Singnomklao T, Rutqvist LE, et al: Adjuvant preoperative radiotherapy in patients with rectal carcinoma: Adverse effects during long term follow-up of two randomized trials. Cancer 78:968976, 1996 